\title{
EFEKTIFITAS PEMBELAJARAN FIQH KONTEMPORER MENGGUNAKAN APLIKASI E-BOOK AL-FIQHUL ISLAMI WA ADILLATUHU DALAM MENGEMBANGKAN SIKAP TOLERANSI PERBEDAAN HUKUM ISLAM DI PONDOK PESANTREN DARUL ULUM AL-FADHALI MERJOSARI LOWOKWARU KOTA MALANG
}

\author{
Abdul Wahid ${ }^{1}$, Rahmadi Setiawan ${ }^{2}$, Mawan Krismawanto ${ }^{3}$ \\ ${ }^{1,2,3)}$ Fakultas Teknologi Industri - ITN Malang \\ Jl. Raya Karanglo Km.2-Malang \\ wahidfilosof@gmail.com
}

\begin{abstract}
ABSTRAK
Artikel ini membahas hasil pengabdian masyarakat tentang pemanfaatan media teknologi informasi yang berupa aplikasi E-book Al-Fiqhul Islami wa Adillatuhu. Ia merupakan salah satu aplikasi yang berisi kompilasi hukum Islam klasik dan kontemporer. Aplikasi ini memuat seluruh hasil kajian kitab klasik dari berbagai madzhab hukum Islam, khususnya madzab fiqh yang empat: Hanafiah, Malikiah, Syafi'iyah, dan Hanabilah, namun dengan corak moderen, mulai dari cara penyajian dan gaya bahasanya. Pemikiran hukum Islam yang terdapat pada aplikasi Ebook Al-Fiqhul Islami wa Adillatuhu didesain dengan pendekatan hukum yang mengkombinasikan pemikiran hukum Islam klasik dan moderen dari seluruh madzhab, termasuk di luar madzhab yang empat. Sehingga hadirnya aplikasi ini memberi manfaat yang besar untuk user dari kalangan santri millenial dalam mengembangkan pemikiran ulama empat madzhab dan lintas empat madzhab dengan nuansa era millenial.
\end{abstract}

Keyword: Aplikasi, eBook, Kompilasi, Fiqh, Kontemporer, Toleransi.

\section{PENDAHULUAN}

Perkembangan teknologi mempunyai implikasi positif pada seluruh aspek kehidupan, tidak terkecuali di bidang pengajaran materi agama Islam. Secara khusus teknologi informasi memberi kemudahan dalam studi hukum Islam. Dengan lahirnya ebook-ebook kajian hukum Islam atau buku-buku elektronik seputar kajian hukum Islam, pengayaan ilmu pengetahuan semakin mudah diperoleh.

Perkembangan ebook pada disiplin ilmu pengetahuan keislaman juga berkembang pesat sampai saat ini. Yang sangat menarik adalah e-book yang dishare oleh masyarakat Muslim di dunia Islam dari Timur tengah pada umumnya dibagikan secara gratis yang harga hardcopy-nya bernilai 4-12 jutaan rupiah.

Sebelum lahirnya ebook studi keislaman, untuk memiliki satu judul buku saja, membutuhkan biaya yang sangat mahal dan membutuhkan energi yang ekstra. Lahirnya teknologi informasi yang termasuk di dalamnya adalah ebook, ternyata sangat memudahkan pengembangan studi hukum Islam. Misalnya, di pesantren-pesantren tradisional dalam kajian hukum Islam dikenal dengan kajian fiqh. Biasanya untuk mengkaji dan mendalami satu kitab kajian hukum Islam, butuh kitab-kitab besar yang berjilid-jilid, yang harganya juga tidak murah.

Perkembangan teknologi informasi saat ini banyak memberi kontribusi akademik dengan buku elektronik kajian hukum Islam dalam bentuk aplikasi. Namun demikian banyak pesantren atau kalangan santri bahkan kalangan muslim secara umum yang belum mengenal dan tidak familiar dengan e-book Islam. Sehingga dari kalangan mereka tidak banyak menggunakan buku-buku elektronik kajian keislaman, baik barupa aplikasi, buku pdf, word, dan lain sebagainya.

\section{TINJAUAN PUSTAKA}

Diantara ebook kajian hukum Islam adalah AlFiqh al-Islami wa Adillatuhu (الفقه الإسلامي و أدلته) yang merupakan kitab fiqh besar di era digital ini. Kitab ini sangat masyhur dan banyak dijadikan rujukan oleh para ulama dunia internasional dan rujukan di pusat-pusat studi Islam. Kitab yang dianggap sebagai sebuah ensiklopedia fiqh dan perundangan hukum Islam ini adalah karya Dr. Wahbah AzZuhaili- seorang ulama kontemporar yang terkenal di dunia Islam.

Konten kitab ini mencakup keseluruhan aspek hukum Islam yang bermula daripada persoalan taharah (bersuci), ibadat, muamalat (tansaksi) dan juga aspek-aspek undang-undang jinayah (kriminal), wasiat, undang-undang keluarga, undang-undang kontrak dan lain-lain.

Metode pembahasan pada kitab ini menekankan metode fiqh perbandingan mazhab (aliran pemikiran hukum Islam), khususnya empat mazhab Ahlu Sunnah wal Jamaah, yaitu mazhab Hanafi, Maliki, Syafii dan Hanbali. Namun begitu, terkadang Dr. Wahbah Az-Zuhaili menyebut juga madzhab lain seperti Imamiyah dari Syi'ah dan Ibadhiyah dari Khawarij sebagai perbandingan karena ada kesamaan hasil ijtihad. Namun demikian, beliau tetap berada pada madzhab sunni.

Ada beberapa kelebihan pada ebook kitab AlFiqhul Islami wa Adillatuhu ini, diantaranya adalah: 
1. Semua hukum Islam yang diterangkan dalam kitab ini disertai rujukan kitab-kitab yang penulis kutip, mulai nama kitab, pengarang, volume (jika berjilid), dan halaman, bahkan rujukan undangundang negara yang disahkan, dsb.

2. Beliau juga melakukan tarjih (pengutamaan pendapat hukum) atas sekian pendapat hukum Islam berdasakan dalil Al-Quran, hadits, ijma', qiyas, dan bahkan sejarah.

3. Analisis kritis yang tajam atas suatu persoalan hukum Islam dan nalar rasional menjadi warna khas yang mempercantik kitab ini.

4. Penulisan dalil huikum dituangkan secara tertib mulai dari dalil Al-Quran, hadits, ijma' dan qiyas.

5. Kontekstualisasi hukum Islam dalam berbagai bidang kajian, misalnya terkait satuan dalam ukuran dan timbangan seperti pada bab zakat, ukuran air, nishab, jarak tempuh perjalanan, dsb. beliau menyajikannya sesuai dengan satuan modern. Misalnya, satu mud +- $2.5 \mathrm{~kg}$, dalam bab fidyah.

Secara umum, ebook kitab Al-Fiqhul Islami wa Adillatuhu sangat layak diapresiasi sebagai karya yang sangat fenomenal dan modern di bidang hukum Islam.

Pada kegiatan pengabdian kepada masyarakat ini bertujuan untuk memberikan pengembangan wawasan fiqh kontemporer dalam pelatihan penggunaan aplikasi ebook Al-Fiqh al-Islami wa Adillatuhu (الفقه الإسلامي وأدلته) yang merupakan kitab fiqh besar di era digital ini. Dengan harapan para santri dapat mengembangkan studi hukum Islam dari kitab-kitab klasik ke kitab-kitab kontemporer menggunakan smartphone. Adapun yang menjadi sasaran pengabdian ini adalah para santri di Pondok Pesantren Darul Ulum Al-Fadhali Merjosari Lowokwaru Kota Malang.

Ebook Al-Fiqhul Islami wa Adillatuhu ini penulis sebut sebagai fiqh kontemporer dari sisi penyajian bahasa, sistematika, dan pendekatan yang betul-betul baru, dan belum ada di zaman ulama salaf (abad 2-4 Hijriah), secara khusus sistematikan penulisan daftar isinya semi ensiklopedi. Dari sisi bahasa misalnya, ebook ini menggunakan bahasa fiqh yang sudah dikontekstualisasikan dengan perkembangan masyarakat moderen. Sehingga sangat efektif untuk pembelajaran hukum Islam di era millenial ini. Karena cukup dengan memiliki smartphone, kitab fiqh yang seharga Rp. 3.500.000an ini sudah bisa dibaca melalui HP. Kalangan pesantren sendiri belum banyak yang memanfaatkan perekmbangan ini. Oleh karenanya penulis ingin memberikan kontribusi akademik di bidang pemanfaatan media teknologi informasi tepat guna bagi masyarakat pesantren.

\subsection{Pengenalan Ketik Huruf Arab}

Semua menu yang terdapat di dalam aplikasi ebook Al-Fiqh al-Islami wa Adillatuhu menggunakan bahasa Arab. Oleh karena itu, sebelum menggunakan aplikasi ebook Al-Fiqh alIslami wa Adillatuhu ini, user harus mampu mengetik dengan huruf Arab pada keyboard HP atau laptop. Untuk user yang menggunakan HP atau smartphone, maka harus mengubah papan ketik HP dari Indonesia ke Arab. Sebagaimana gambar berikut:

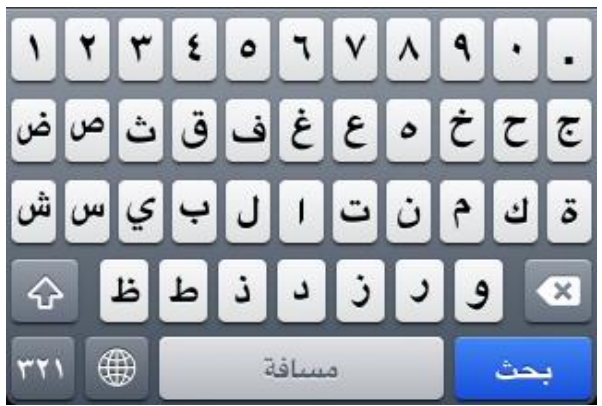

Gambar 1. Papan Ketik HP

Setelah berubah sebagaimana pada gambar di atas, bukalah aplikasi ebook. Namun demikian, bagi user smartphone tentunya harus mendownload di playstore, atau melalui google. Jika dowload di google, maka nanti memilih menu sebagaimana yang penulis tampilkan pada sub bab berikut ini. Baik pengguna/user laptop atau android akan lebih mudah mendownload melalui situs resmi yang meng-share ebook ini. Karena terkadang di playstore layanan ebook ini tidak tersedia. Untuk periode 2019 penulis mengecek di playstore sudah tidak ada. Maka soluisinya masuk situs resminya sebagaimana pada pemaparan penulis berikut:

\subsection{Petunjuk Penggunaan Ebook Al-Fiqhul Islami wa Adillatuhu}

Setelah komputer, laptop, atau smartphone user bisa ketik huruf arab, maka kunjungi situs: http://www.shamela.ws/

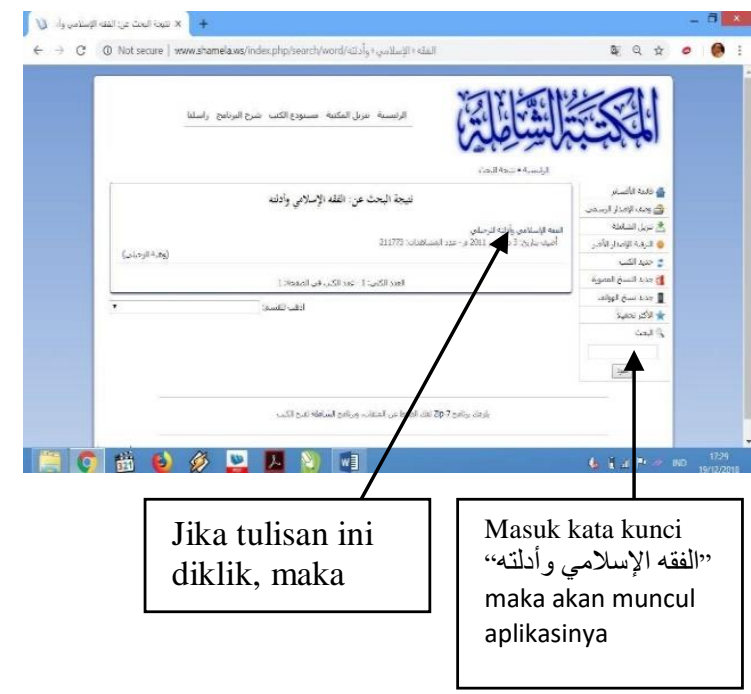

Gambar 2. Situs Apl ikasi Ebook Al-Fiqhul Islami 


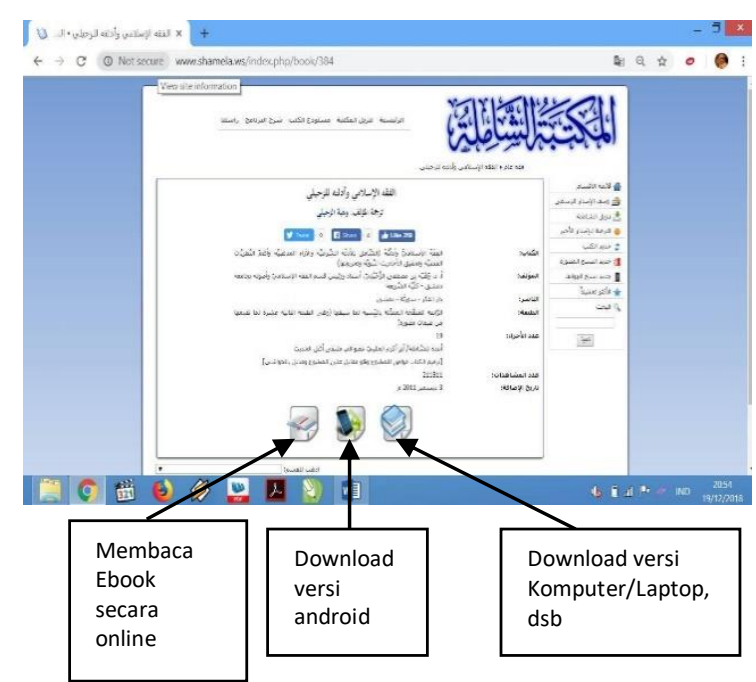

Gambar 3. Pemilihan Download

Sebagaimana pada gambar di atas setelah masuk situs resmi, user akan ditunjukkan pemilihan 3 opsi peruntukan aplikasi. User bisa memilih 1 . Untuk membaca secara online, 2. Download untuk android, 3. Download untuk laptop, komputer dan lain sebagainya. Artinya, mendownload ebook ini akan lebih lengkap bila masuk situs resminya. Bisa mendownload untuk laptop, komputer, membaca online, dan bisa untuk smartphone. Jika di playstore tidak tersedia, maka user langsung membuka situs resmi sebagaimana yang penulis paparkan di atas.

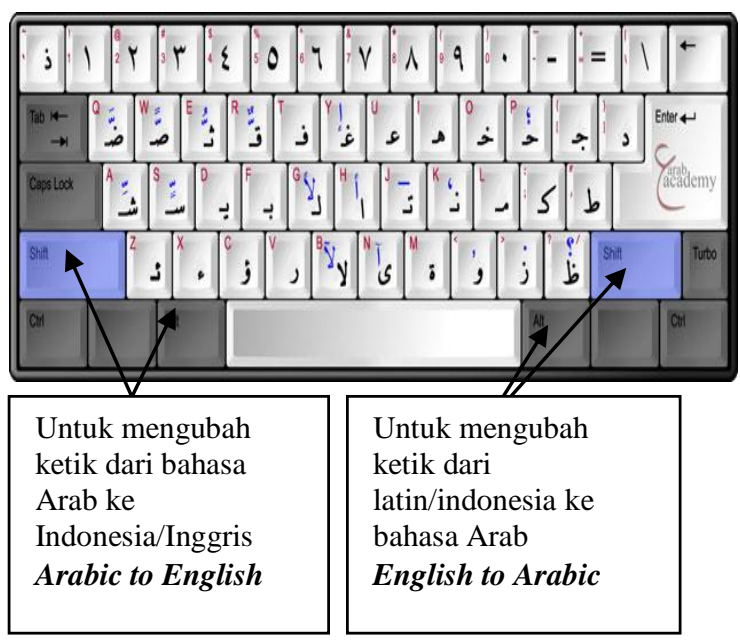

Gambar 4. Keyboard Komputer

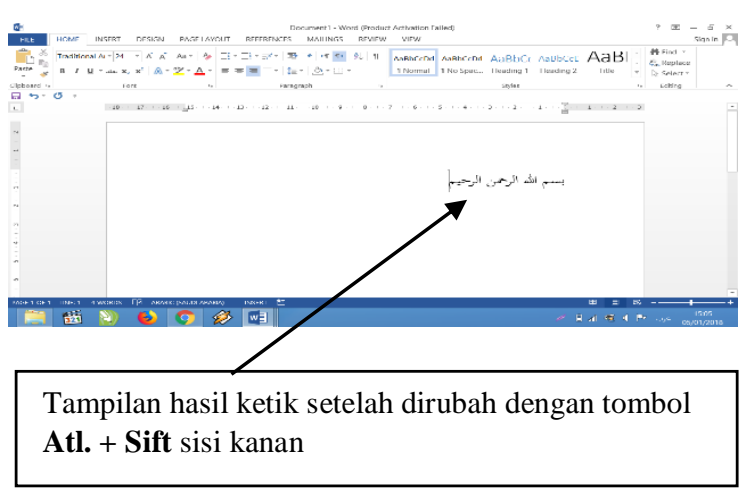

Gambar 5. Tampilan Hasil Ketik Arab

Bila laptop atau PC sudah bisa dipastikan ketik huruf arab, maka langkah berikutnya adalah mengunduh aplikasi ebook Al-Fiqh al-Islami wa Adillatuhu. Penggunaan bahasa pada aplikasi ini semuanya berbahasa Arab. Sehingga bisa diasumsikan bahwa yang bisa memanfaatkannya adalah user/pengguna yang mempunyai kemampuan bahasa Arab.

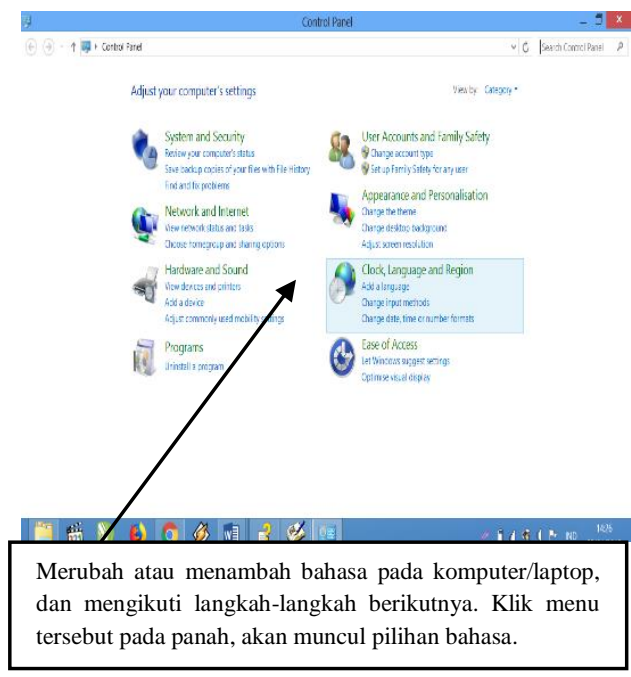

Gambar 6. Mengubah Ketik Huruf Arab Pada Komputer

\subsection{Mengubah Huruf Arab Pada Keyboard}

Untuk mengubah hasil ketik pada keyboard dari latin/indonesia/inggris ke bahasa Arab sangatlah mudah, cukup tekan Alt.+Sift sisi kanan, maka akan berubah ketik arah kanan ke kiri/bahasa Arab. Untuk mdengembalikan dari Arab ke latin/indonesia/inggris, cukup tekan Alt.+ Sift sisi kiri, maka ketik huruf akan berubah dari kiri ke kanan. 


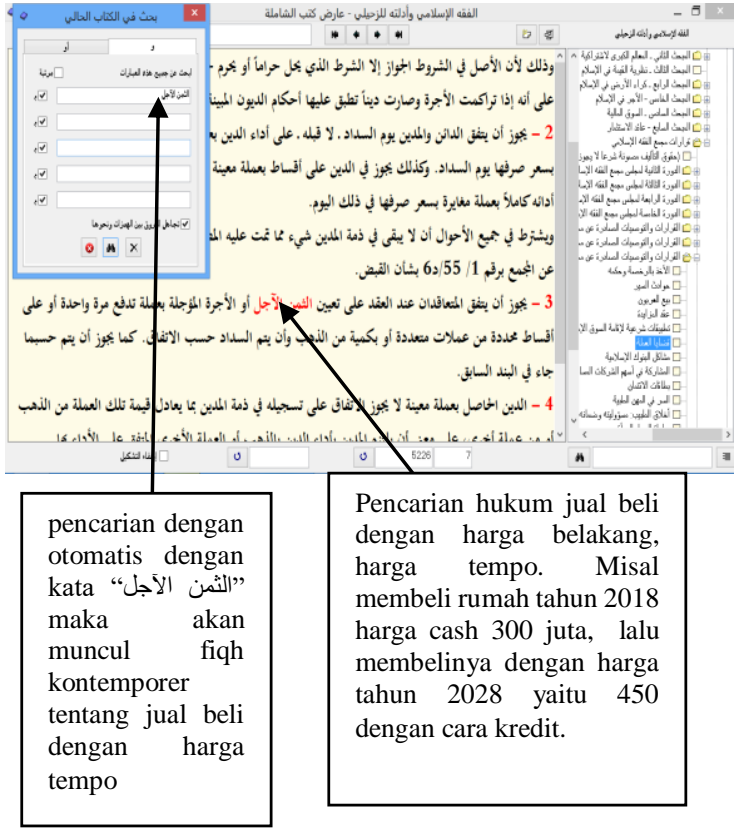

Gambar 7. Gambaran Implementasi

Dengan melihat hasil di atas user dapat mengetahui status hukum pembelian kredit dan cash menurut hukum Islam Islam. Yang mana di zaman Rasulullah SAW belum ada praktik jual beli kredit. Dengan fiqh kontemporer ini para santri bisa mengembangkan keilmuannya di bidang hukum Islam seperti dalam contoh di atas.

\section{METODE PENELITIAN}

Dimulai dengan persiapan penelitian, pengamatan, survei pustaka, survei kurikulum, penggunaan media pembelajaran di Ponpes AlFadhali, dan informasi tentang pemanfaatan teknologi informasi untuk pembelajaran fiqh serta efektifitasnya, khususnya aplikasi ebook Al-Fiqh alIslami wa Adillatuhu.

Pada tahap persiapan, segala kebutuhan penulis data dalam bentuk pengelompokan antara kebutuhan primer dan sekunder. Kemudian masuk tahapan pembuatan soal-soal untuk menguji efektifitas aplikasi untuk pembelajaran fiqh dengan aplikasi ebook. Peneliti melibatkan beberapa ustadz dan wakil pengasuh untuk mengamati dan mengevaluasi, sekaligus melakukan komparasi antara belajar fiqh menggunakan buku, dengan menggunakan aplikasi ini. Berikut skemanya:

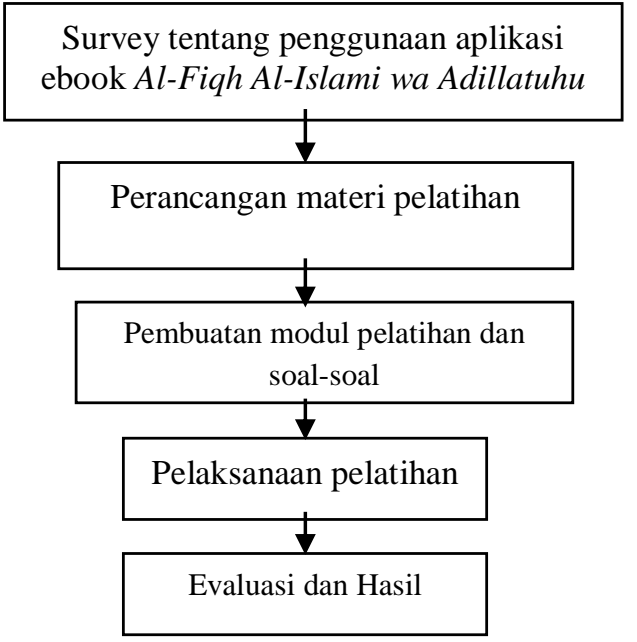

Gambar 8. Persiapan Penelitian

Dari pemaparan singkat di atas metode yang peneliti gunakan adalah metode analisis konten dan komparasi. Dalam hal ini membanding antara belajar fiqh menggunakan buku teks, dengan buku digital. Perbandingan ini bertujuan untuk mengetahui sejauh mana efektifitasnya pembelajaran dengan memanfaatkan teknologi dan buku teks. Adapun media-media yang peneliti gunakan adalah:

Adapun alat-alat penelitian yang digunakan dalam adalah:

1. Modul pelatihan

2. Aplikasi Ebook Al-Fiqhul Islami

3. HP Android/Laptop santri

4. Mouse masing-masing santri

5. Keyboard

6. Printer tuk cetak hasil belajar

7. Buku-buku fiqh manual

\subsection{Target Kegiatan}

Kegiatan pengabdian kepada masyarakat ini bertujuan untuk memberikan pelatihan penggunaan aplikasi ebook Al-Fiqh al-Islami wa Adillatuhu (الفقه yang merupakan kitab fiqh besar di era digital ini. Sehingga diharapkan para santri dapat mengembangkan studi fiqh dari kitab-kitab klasik ke kitab-kitab kontemporer dengan basis komputer dan smartphone. Adapun yang menjadi sasaran pengabdian ini adalah para santri di pesantren mahasiswa Darul Ulum Al-Fadhali Merjosari Lowokwaru Kota Malang.

1. Santri dari kalangan mahasiswa di pesantren Darul Ulum Al-Fadhali Merjosari Lowokwaru Kota Malang.

2. Santri senior yang sudah diperbantukan sebagai wakil kyai di pesantren mahasiswa Darul Ulum Al-Fadhali Merjosari Lowokwaru Kota Malang.

3. Para santri dan pemerhati studi hukum Islam era millenial 


\subsection{Kerangka Pemecahan Masalah}

Kerangka pemecahan masalah diuraikan seperti skema di bawah ini:

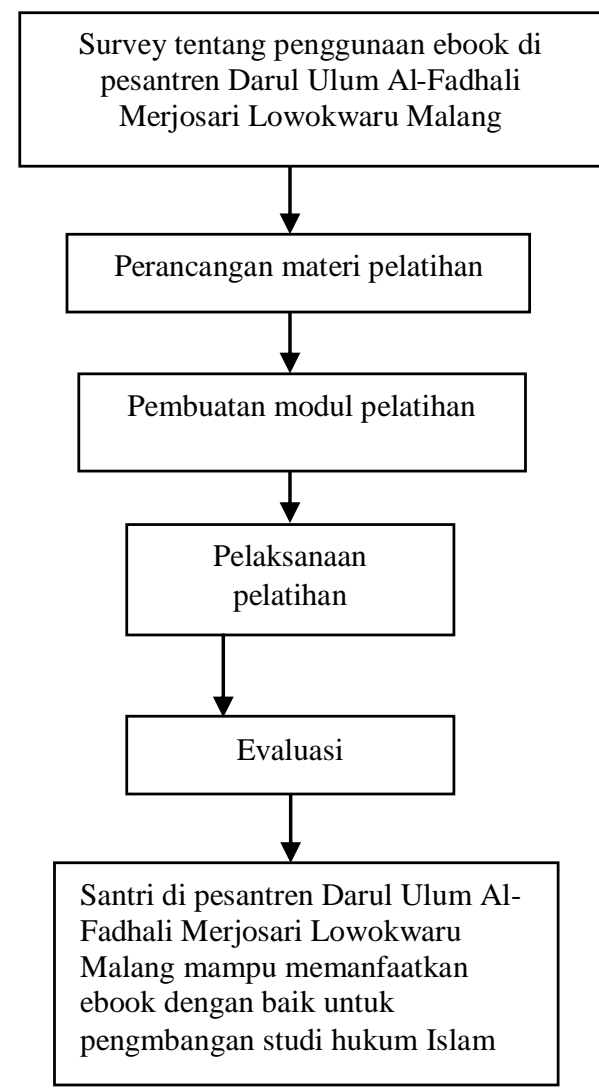

Gambar 9. Kerangka Pemecahan Masalah

\section{HASIL DAN PEMBAHASAN}

\subsection{Pembahasan}

Rancangan media dalam penelitian ini meliputi pengenalan ketik huruf Arab, instal aplikasi, dan modul pelatihan untuk seluruh peserta, diakhiri praktek dan evaluasi. Adapun rinciannya adalah sebagai berikut:

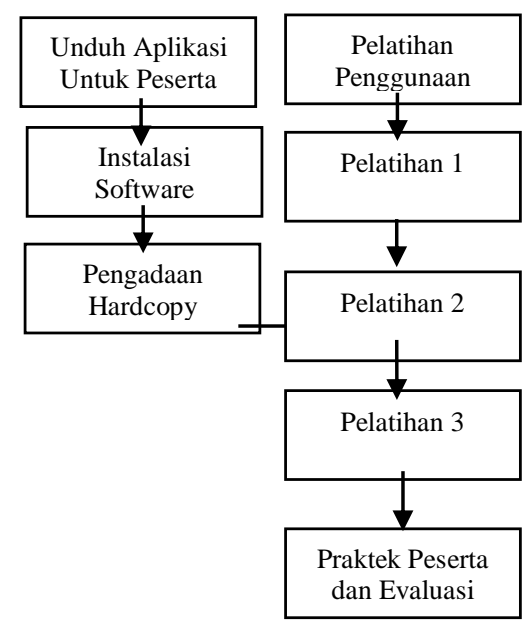

Gambar 10. Rancangan Penelitian

\subsection{Efektifitas Penggunaan Ebook Al-Fiqhul Islami wa Adillatuhu}

Berdasarkan langkah-langkah pada pelatihan penelusuran hukum fiqh kontemporer dengan menggunakan aplikasi ebook Al-Fiqhul Islami wa Adillatuh di Pondok Pesantren Al-Fadhali Merjosari Malang, hasil pernyataan para peserta sebagai berikut:

1. Teknologi informasi sangat memudahkan dan efektif untuk pembelajaran ilmu studi Islam, khususnya di bidang masalah-masalah kontemporer yang belum ada di zaman Rasulullah SAW.

2. Aplikasi ebook Al-Fiqhul Islami wa Adillatuh sangat mudah untuk diimplementasikan sebagai media pembelajaran, pendalaman, penelitian, dan pengembangan studi hukum Islam yang bersifat moderen.

3. Studi Islam atau keilmuan agama Islam akan lebih mudah, lebih efektif, dan lebih efesien dengan memanfaatkan kecanggihan teknologi informasi.

4. Pesantren dituntut juga untuk pengembangan pembelajaran dengan menjadikan teknologi informasi sebagai sarana belajar.

Tabel 1. Evaluasi dan Hasil

\begin{tabular}{|c|c|}
\hline Hasil Pelatihan & Kompetensi User \\
\hline $\begin{array}{l}\text { 1. Penulis menyusun } \\
\text { modul pelatihan } \\
\text { mengetik dengan } \\
\text { huruf arab yang akan } \\
\text { digunakan santri- } \\
\text { santri Ponpes Al- } \\
\text { Fadhali }\end{array}$ & $\begin{array}{l}\text { 1. Santri-santri } \\
\text { mampu memahami } \\
\text { dan mempraktikan } \\
\text { isi modul dengan } \\
\text { baik. }\end{array}$ \\
\hline $\begin{array}{l}\text { 2. Modul pelatihan } \\
\text { yang digunakan para } \\
\text { peserta dari kalangan } \\
\text { santri ponpes Al- } \\
\text { Fadhali Merjosari } \\
\text { Malang }\end{array}$ & $\begin{array}{l}\text { 2. Santri-santri } \\
\text { mampu } \\
\text { mengimplementasi } \\
\text { kan modul pelatihan } \\
\text { mulai instalasi dan } \\
\text { penggunaan menu- } \\
\text { menu pada toolbar }\end{array}$ \\
\hline $\begin{array}{l}\text { 3. Pembelajaran dan } \\
\text { pelatihan instalasi } \\
\text { pengubahan ketik } \\
\text { bahasa Indonesia ke } \\
\text { Bahasa Arab }\end{array}$ & $\begin{array}{l}\text { 3. Para santri mampu } \\
\text { mengetik huruf arab } \\
\text { pada keyboard } \\
\text { untuk Ms. Word. }\end{array}$ \\
\hline $\begin{array}{l}\text { 4. Dengan satu aplikasi } \\
\text { ebook ini santri sudah } \\
\text { memiliki kitab yang } \\
\text { senilai } 3.500 .000\end{array}$ & $\begin{array}{l}\text { 4. Para santri bisa } \\
\text { melakukan } \\
\text { pencarian hukum- } \\
\text { hukum kontemporer } \\
\text { dengan baik }\end{array}$ \\
\hline
\end{tabular}

\section{KESIMPULAN DAN SARAN}

\subsection{Kesimpulan}

Berdasarkan hasil akhir dari pelatihan pembelajaran fiqh kontemporer dengan aplikasi ebook الفقه الإسلامي و أدلته penulis mendapatkan beberapa kesimpulan sebagai berikut:

1. Efektifitas pembelajaran fiqh kontemporer ebook Al-Fiqhul Islami wa Adillatuhu sangat signifikan, karena dengan menggunakan aplikasi 
ini pengetahuan dan wawasan hukum Islam tentang perkara-perkara baru yang tidak dijumpai secara praktis di masa Rasulullah SAW namun konsep besarnya sudah ada.

2. Aplikasi ebook ini sangat cocok untuk pembelajaran fiqh kontemporer di lingkungan pesantren-pesantren sebagai bahan ajar dan media pembelajaran hukum Islam, sekaligus untuk menumbuhkan nilai-nilai toleransi pada perbedaan hukum Islam di dalam madzhabmadzhab hukum Islam. Karena di dalam ebook ini diajarkan seluruh madzhab hukum Islam tanpa fanatisme pada golongan tertentu.

3. Memudahkan para santri untuk mengembangkan dan memperluas wawasan keislaman di bidang hukum Islam

4. Memudahkan para ustadz dan para pengajar materi hukum Islam dengan model perbandingan antar madzhab fiqh.

5. Menghemat biaya pengadaan buku-buku, karena aplikasi ini bisa didownload secara gratis, yang mana jika membeli hardcopy-nya membutuhkan anggaran setidaknya Rp. 3.500.000 untuk 1 copy buku ini.

6. Memudahkan masyarakat pesantren untuk melakukan pengembangan dan kontekstualisasi konsep-konsep hukum Islam klasik di era modern.

\subsection{Saran}

1. Penulis menyarankan kepada pihak lembaga pendidikan Islam untuk menjadikan aplikasi ini sebagai bahan ajar fiqh karena ebook Al-Fiqhul Islam wa Adillatuh bisa mewakili kitab-kitab fiqh yang paling klasik dan yang paling kontemporer.

2. Untuk pihak Institut Teknologi Nasional Malang Jurusan Informatika bisa menjadi mitra pesantren-pesantren untuk pengembangan aplikasi-aplikasi ebook studi Islam.

3. Untuk perguruan tinggi teknologi secara umum sudah saatnya juga melakukan pengembangan di bidang pembuatan ebook, baik ebook Islam atau umum. Karena mengingat era millenial, semua lapisan masyarakat bergantung pada IT, termasuk di bidang materi bacaan dan pembelajaran.

\section{DAFTAR PUSTAKA}

[1]. http://www.shamela.ws/Az-Zuhaily, Wahbah, Fiqhul Islam Wa Adillatuhu, (Damaskus: Dar al-Fikr, 2007)

[2]. Ramadhani, Mawar 08520241028 Program Studi Pendidikan Teknik Informatika Fakultas Teknik Universitas Negeri Yogyakarta Efektivitas Penggunaan Media Pembelajaran E-Learning Berbasis Web Pada Pelajaran Teknologi Informasi Dan Komunikasi Terhadap Hasil Belajar Siswa Kelas X Sma Negeri 1 Kalasan, http://eprints.uny.ac.id /30140/1/Mawar\%20Ramadhani\%200852024 1028.pdf,

[3] . Rosida, Noor Fadiawati, Tri Jalmo Magister Keguruan IPA FKIP Unila Jl. Prof. Dr. Soemantri Brojonegoro No. $1 *$ Corresponding author, HP:082232172323, email:rosidagr@ gmail.com, Efektivitas Penggunaan Bahan Ajar E-Book Interaktif Dalam Menumbuhkan Keterampilan Berpikir Kritis Siswa, https://media.neliti.com/media/publications/11 6746-ID-efektivitas-penggunaan-bahan-ajare-book.pdf,

[4]. L Andikaningrum, W Damayanti, C Dewi 2014 - repository.uksw.edu Efektifitas Ebook Berbasis Multimedia Menggunakan Flip Book Maker Sebagai Media Pembelajaran Dalam Meningkatkan Keaktifan Belajar Siswa, http://repository.uksw.edu/bitstream/1234567 89/5122/3/T1_702010024_Full\%20text.pdf

[5]. http://lipi.go.id/berita/ebook-dan-pasarperbukuan-kini/6669

[6]. http://www.mustanir.com/mengenal-AlMausuat-al-fiqhiyyah-al-kuwaitiyyah/

[7]. Sadiman S, Arif (2008). Media Pendidikan: Pengertian, Pengembangan, dan Pemanfatannya. Jakarta: PT. Raja Grafindo Persada 